\title{
Interlocution after liberation: Who do we interpret with and which biblical text do we read with?
}

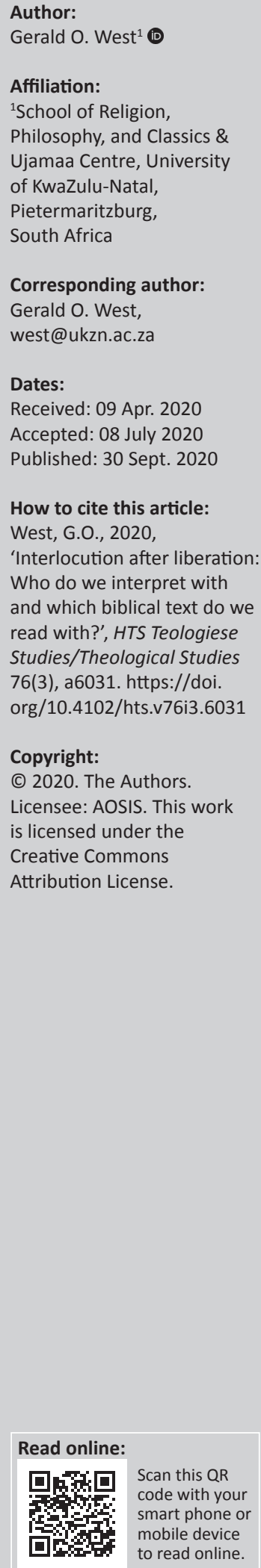

This article aims to point out two seminal reflections on interlocution: Frostin's insightful late1980s (1988) analysis of 'Third World' liberation theologies and his contention that the decisive question for liberation theologies was the question of who the primary dialogue partners of liberation theology have been and should be, and Vuyani Vellem's more recent millennial (2012) reflection on how South African Black Theology after liberation has grappled and should grapple with the notion of interlocution. My choice of these two scholars is not idiosyncratic, for Vellem uses Frostin's work as one of his starting points. I build on this conversation, reflecting with Vellem on how we might understand the issue of interlocution within black and kindred liberation and prophetic theologies today. My particular emphasis is on biblical hermeneutics; therefore, my contribution to the conversation frames my reflections within a particular phase of Black Theology in which the Bible is most significantly problematised, what Tinyiko Maluleke refers to as the second phase of Black Theology. The conundrum Itumeleng Mosala poses for Black Theology is how the recognition of the Bible as itself - intrinsically, inherently and indelibly - 'a site of struggle' reconfigures interlocution. Mosala, I will argue, forces us to not only ask who we interpret with when we do Black Theology, but also ask which biblical texts we read, for not all biblical texts offer resources for liberation.

Contribution: This article makes a contribution to the VukaniBantuTsohangBatho-Spirituality of Black Liberation collection in which the work of Vuyani Vellem is celebrated and critically engaged. Specifically, the article interrogates and contributes to Vuyani's Vellem understanding of 'locution', and asks how this concept impacts our understanding of biblical text.

Keywords: Black Theology; Epistemological privilege of the poor; Liberation theology; African biblical hermeneutics; Decolonial.

\section{Introduction}

In the midst of the struggle against apartheid, in the mid-1980s, the Swedish theologian Per Frostin (1988) compiled and published his seminal analysis of Third World liberation theologies in general and two African liberation theologies in particular: Liberation Theology in Tanzania and South Africa: A First World Interpretation. The title does not do justice to the general dimension of Frostin's work. The introductory 26 pages of his book provide the conceptual apparatus for what follows as a vast amount of Third World documentation is assembled and analysed. What was and remains rare is how a self-acknowledged 'First World' theologian entered the emic world of Third World theologies. The fine-print endnotes and bibliography make up one-third of the book, providing a rich archive from which Frostin established the arguments he made about Third World liberation theologies. Frostin's (1988:20) work offers us 'the methodological selfunderstanding of Third World theologies within EATWOT' (Ecumenical Association of Third World Theologians).

Frostin (1988:6) finds an emerging 'new paradigm' within EATWOT reflections on theological work across Third World contexts. Frostin (1988) discerns that this new paradigm:

$[M]$ ay be defined in reference to five interrelated emphases: the choice of 'interlocutors', the perception of God, social analysis, the choice of theological tools, and the relationship between theory and practice. (p. 6)

The ordering of the first emphasis is deliberate, for it provides a decisive shape to the other four emphases and therefore to liberation theologies. 'Third World experience' identifies 'social relations' as a key site of struggle for the doing of theology and 'the poor' as the primary dialogue partners within this site of struggle (Frostin 1988:6). The choice of who the primary interlocutors

Note: Special Collection entitled VukaniBantuTsohangBatho - Spirituality of Black Liberation, sub-edited by Fundiswa Kobo (UNISA) and Rothney Tshaka (UNISA). 
of liberation theologies are 'has important consequences not only for the interpretation of social reality but also for the understanding of God', given that 'the epistemological privilege of the poor' encompasses both the poor's 'perception of the social reality' and the poor's 'understanding of God' (Frostin 1988:6, 7). 'Logically', Frostin (1988) continues, establishing the shape of liberation theologies as he moves from the first and second emphasis to the third:

[T] he option for the poor as the chief interlocutors of theology is based on a conflictual perception of the social reality, affirming that there is a difference between the perspectives of the privileged 'from above' and of the poor 'from below'. (pp. 7-8)

'Struggle', which both South African Contextual Theology and South African Black Theology would refer to as 'conflictual analysis', was central to social analysis (Frostin 1988:8). The fourth emphasis cohered, Frostin (1988:9) argued, with the methodological logic established by the three emphases that preceded it, for by privileging the reality and epistemology of the poor, theology required 'the social sciences' 'to define which persons ... belong to this group' and to analyse the intersecting 'power relations' that constitute the lived experience of the poor. The fifth and final emphasis situates theology as the 'second act', following and dependent on a prior 'commitment to the liberation of the oppressed', the 'first act' (Frostin 1988:10).

I have elaborated Frostin's logic of liberation theology methodology in order to establish how important the first emphasis is, giving shape as it does to liberation theologies (for a fuller discussion on this topic, see West 2013, 2015, 2017a). The choice of interlocutor is crucial to the doing of theology. It is understandable, therefore, that in reflecting on South African Black Theology after the substantial but partial liberation of 1994, Vuyani Vellem identifies 'interlocution' as a vital concept for further interrogation within South African Black Theology (Vellem 2012; see also Vellem 2020). ${ }^{1}$ A significant component of Vellem's contribution to the Black Theology project has been his interrogation of just who is granted an epistemological privilege in post-apartheid liberation and/or prophetic theologies. In the next section of this article, I take account of Vellem's analysis. I then offer my own contribution to the ongoing work of Black Theology, returning to the hermeneutical conundrum Itumeleng Mosala posed in the mid-1980s. If it is true, as Mosala argues and as Vellem affirms (Vellem 2020:6), that the Bible is itself, in terms of its sites of production, an ideo-theological site of struggle, then what texts do we appropriate and how do we do the appropriation in ways that are inclusive of Vellem's 'voiceless' (Vellem 2012:1)?

1.The 2020 essay cited here is one of Vuyani Vellem's final published pieces (which cite in its proof form, so the page numbers cited are with respect to the essay itself not the volume as a whole). He presented the paper version of this essay at the not the volume as a whole). He presented the paper version of this essay at the Council for World Mission's 2017 'DARE Global Forum', in Bangkok, Thailand. There was considerable overlap between his paper and mine (published as West 2019a) in the area of biblical hermeneutics and so our conversations there were deep and profound. We continued the conversation thereafter, both in our South African contexts and again at the 2019 'DARE Global Forum' in Taipei, Taiwan. Vuyan Vellem, a colleague and friend, has left the conversation too soon. This article is tribute to that conversation. May its echoes be taken up by others.

\section{Interlocution and post-1994 voicelessness}

Vellem's (2012) starting point with respect to 'interlocution' is an affirmation of Frostin's arguments. Firstly, Vellem (2012:2) acknowledges that the choice of an interlocutor is a key to distinguishing one form of theology from the other', echoing not only Frostin's formulation but also Frostin's argument: 'Black Theology of liberation has distinguished itself from Western orthodox theology by choosing the "non-person" as its interlocuter' (Vellem 2012:2). For both Frostin and Vellem theology is a site of struggle, and therefore it is important to distinguish one theology from another, with the choice of interlocutor being the decisive factor in the identification of a theology.

Secondly, although standing in the trajectory of 'black experience' (Frostin 1988:85-103) as fundamental to Black Theology, Vellem follows Tinyiko Maluleke in probing the precise community that constitutes the interlocutor of Black Theology. Referring to Maluleke (1996), who cites Mosala (1989b:143), Vellem (2012:2) argues that 'class is an important aspect and that not every black person is necessarily an interlocutor of Black Theology of liberation'. Given the methodological priority of the choice of interlocutors, Vellem (2012:2) probes the identity of interlocutors of South African Black Theology after 1994, attempting to identify 'the elusive interlocutor of democratic South Africa'. Although I am not sure that Vellem has fully grasped Maluleke's position, Vellem himself is clear about his own stance. Class is a significant feature in identifying Black Theology's interlocutor. Indeed, in answering the question, 'where do we ... locate our interlocution for urban black public theology?', Vellem $(2014: 4,6)$ not only identifies the black, apartheid built, kassie [location] as the race and/as classbased site with whom Black Theology must be done, but goes on to argue that it is from such sites that Black Theology 'must continue to search unabated for metamorphosed, home-made resources of language and symbols that the poor employ against alienating forces of urbanisation and the displacement of life-giving sources'.

Referring again to Frostin's use of Gustavo Gutiérrez's notion of 'nonpersons' as the primary interlocutor of liberation theologies (Frostin 1988:6; Gutiérrez 1978:241), Vellem (2012:3) recognises 'a shift' post-1994 in interlocutor from non-persons to middle-class persons. 'This kind of shift', Vellem (2012:3) continues, 'is discernable in a number of discourses that became prevalent in our public life so far'. Amongst the discourses that have abandoned non-persons in favour of middle-class persons, Vellem (2012:3) identifies the state's discourse concerning Affirmative Action, the church's shift from critical solidarity with the poor to 'critical solidarity with the state' and the Truth and Reconciliation Commissions' emphasis on reconciliation rather than justice (see also Vellem 2013:8). Had Vuyani Vellem been amongst us during this time of Coronavirus disease 2019 (Covid-19), he would have 
engaged us in conversation about how so much of the early public discourse about social distancing, hand-washing, etc., was oriented to South Africa's middle-classes rather than the vulnerable, including the homeless, those living in shack settlements, the unemployed, casual workers, the elderly and those living with disability.

Having recognised this shift from non-persons or 'nonbeings' (Vellem 2020) to middle-class persons, Vellem (2012:5) summons Black Theology (back) to intersecting 'interlocution and economic liberation'. Contrasting middle-class 'talk' with 'voicelessness', Vellem (2012:3, 5-7) constructs democratic South Africa as a site of economic struggle. Vellem (2012) acknowledges the post-1994 attempts to:

[E]xpand the tradition of Prophetic Theology to include other modes of moral discourse so as to include rational, apologetic modes of argumentation between prophets and policy makers in public life. (p. 7)

But at the same time he worries that such forms of Prophetic Theology have made the mistake of 'the loss of interlocutor'. Vellem argues that Black Theology, even after 1994, should not make the same mistake. 'Black Theology of liberation, by making a vivid choice of the community of interlocutors, concretises the historical project of the envisioned alternative community by the prophets' (Vellem 2012:7). Following Maluleke's admonition about the subjectivity and agency inherent in the notion of interlocutor (Vellem 2020:2), Vellem rejects middle-class talk of prophetic theology in favour of the voiceless as interlocutors. The biblical vision of the prophets, he insists, is 'historicised even though such a choice might be difficult' (Vellem 2012:7).

Vellem probably has a number of factors in mind when he says 'such a choice might be difficult'. As his analysis has shown, identifying a particular sector as interlocutors in a post-liberation democratic context is difficult. Furthermore, insisting on the (black) voiceless as the primary interlocutors of post-apartheid forms of Black Theology when the trend within our democracy is towards the (black) middle class is also difficult. In the next section of this article, I want to add another difficulty. If the poor and marginalised voiceless are to be actual interlocutors of Black Theology, then they must be included in the actual doing of theology. No black theologian would dispute this. But what does this mean for biblical interpretation if we are to heed the analysis of Mosala about the Bible being a site of struggle? How do the voiceless in contemporary South Africa identify and appropriate the voice of the voiceless in the Bible?

\section{The Bible as a site of struggle}

Whilst the Bible cannot be the primary starting point for Black Theology, Mosala (1986) concedes that there are enough contradictions' within biblical texts:

$[T$ ]o enable eyes that are hermeneutically trained in the struggle for liberation today to observe the kin struggles of the oppressed and exploited of the biblical communities in the very absences of those struggles in the text. (p. 196)
The contradictions are present within the text, Mosala (1986:196) continues, because the Bible is itself 'a product and a record of class struggles'. Significantly, Mosala here aligns his hermeneutic of reception with his hermeneutic of production. What is not clear, however, is how these 'Black masses' (Mofokeng 1988:40) - to use Takatso Mofokeng's term - or black 'working class people' (Mosala 1996:43) or 'commoners' (Mosala 1989a:97) - to use Mosala's terms - are to access the 'absences' of their ancient comrades' voices in the text.

If the contemporary 'voiceless', to use Vellem's term, do through their struggle trained eyes 'discover kin struggles in biblical communities', then there is the potential, argues Mosala (1989a:188), that ' $[t]$ hese biblical struggles ... serve as a source of inspiration for [their] contemporary struggles, and as a warning against their co-optation'. However, the enduring problem, according to Mosala, is that the final form of the Bible we have and use is a form shaped by the dominant classes of particular historical periods in the Bible's formation. Dominant classes have through the redactional processes of the Bible's composition co-opted the ideological perspectives of marginalised social sectors. Ideological redactional co-optation of the voices of the marginalised is a distinctive feature of the final form of the biblical text, and so often, says Mosala (1989a):

[T] he category of the 'black struggle' as a hermeneutical factor draws its poetry from a future that in this struggle's collision with ... [much of the biblical text as we have it] is experienced as an 'absence'. (p. 188)

By focussing on the final form of the biblical text we find only the absences of marginalised voices. But this absence is partially present because the redactional processes of dominant sectors never entirely eradicate the voices of marginalised sectors they co-opt. Remnants or fragments of marginalised voices remain. The poetry that Mosala refers to is the capacity of future contexts of struggle, such as the South African post-1994 struggles, to provide avenues of access to the fragmentary presence of ideologically co-opted social sectors.

But how is this to be done, considering the deliberate redaction of marginalised voices in the production of almost any biblical text and the Bible as a whole? James Cone, as I have recently argued (West 2019b), would ask us to trust a radical hermeneutic of reception. 'I believe', says Cone (1979:180), 'that we find our common vision of the Gospel through a serious encounter with the biblical message as defined by our common historical commitment in our various social contexts'. Mosala is not convinced. He approves of Cone's first hermeneutic move, namely, that 'the black experience of oppression and exploitation provides the epistemological lens through which to perceive the God of the Bible as the God of liberation' (Mosala 1989a:15, referring to Cone 1975:31). But Mosala rejects Cone's second hermeneutic move with respect to the Bible. Mosala is not as sure as Cone is, that 'Scripture' 'establishes limits to white people's use of Jesus Christ as a confirmation of black oppression' (Mosala 1989a:15, 
referring to Cone 1975:31). More specifically, Mosala is concerned by Cone's singular claims about 'the witness of Scripture' or 'the biblical message' (Cone 1975:31, 1979:180 [my emphasis]; see Mosala 1989a:15).

Mosala (1989a:16) rejects any claim about the Bible as the 'nonideological Word of God'. Whilst Mosala is willing to accept with Cone 'that it is a biblical truth that God sides with the oppressed in their struggle for liberation', he is quick to counter, saying, 'but, as any hermeneutics deriving from the crucible of class struggle will attest, the biblical truth that God sides with the oppressed is only one of biblical truths' (Mosala 1989a:16, my emphasis). Mosala (1989a) insists that the Bible:

$[I] \mathrm{s}$ rent apart by the antagonistic struggles of the warring classes of Israelite society in much the same way that our world is torn asunder by society's class, cultural, racial, and gender divisions. (p. 16)

The Bible is a site of struggle, inherently, intrinsically and indelibly. Just as there is no non-ideological interpretation of the Bible, a proposition readily accepted by Cone, for Mosala there is no non-ideological biblical or 'scriptural' text.

I have analysed the hermeneutic tension between Cone and Mosala in more detail elsewhere (West 2019b), but I reiterate some of the key conceptual differences here because I want us to hear Mosala's concern clearly. Mosala does not dispute the importance of a hermeneutic of reception. Indeed, it is the starting point of his black biblical hermeneutic of liberation. Mosala's contention is that a hermeneutic of reception is not enough on its own. It must be aligned to a hermeneutic of production (West 2020). If we are to use 'the Bible as a weapon of ideological and spiritual struggle for liberation' (Mofokeng 1988:39), then we should not engage in a 'useless sparring with the ghost of the oppressor ... in the oppressor's most dangerous form, the [final] ideological form of the [biblical] text' (Mosala 1989a:28). Instead, we need to harness the resources of biblical studies in order to probe beneath the final ideo-theological agenda of any biblical text, for it is only, insists Mosala (1989a:185), '[w]ith the agenda of the text laid bare' that 'we can make hermeneutical connections with similar agendas in the contemporary setting'.

Working with the Bible in this way is difficult. Mosala's (1989a:101-153) work on Micah not only demonstrates the complexity but also the necessity of the task. Briefly, beginning with the final form of the book of Micah, but re-reading the biblical book of Micah backwards, Mosala (1989a:118) identifies the final canonical form as arising 'out of the tributary mode of production represented by the Israelite monarchy'. The most 'fundamental means of production' in ancient Palestine 'was the land' (Mosala 1989a:3), which was gradually controlled by an emerging monarchic sacred economy, whereby 'the incipient [monarchic] kingdom required a system of surplus extraction whose presupposition is unrewarded human labor' (Mosala 1989a:107), constructing a 'class structure' that was characterised by 'a social division of labor resulting in antagonistic social relations of production, exchange and distribution' (Mosala 1989a: 115). Mosala (1989a:131) argues that the final redactional form of Micah 'frames' the various other class voices in such a way that it 'relegates' these voices 'to a secondary position'. The scribe who represents the voice of the prophet Micah occupies a class position within the retainer middle layer of ancient Israel, serving the ruling class groups (including the royal house, city-temple priests, imperial representatives and latifundaries) and subsisting on their patronage (Mosala 1989a:117). The scribal representation of the oral voice of the prophet Micah negotiates with but adapts itself to the ruling class, which 'made up 2 percent or less of the population yet controlled half or more of the total goods and services produced in the society' (Mosala 1989a:116). The oral voices of the 'exploited classes', whether the voice of peasants with land tenure, peasants who had lost their land through debt and worked as tenant farmers on the estates of latifundaries, or landless peasants (Mosala 1989a:117), find oral representation in the voice of the prophet Micah, again in negotiated terms, although with an oppositional ideological orientation.

Vellem (2013:6) laments 'the lapse of Christianity in South Africa into church theology after the demise of apartheid'. In my own work, I have argued that what has enabled this lapse theologically has been an uncritical alliance by both the South African church and state with the ideo-theology of dominant sectors that have controlled the final form of the Bible (West 2017b). Although Vellem acknowledges Mosala's argument about the Bible as itself, inherently and indelibly, a site of struggle, his emphasis is less on the struggle in the text and more on the struggle about who reads the text. According to Vellem (2020:5-6), 'democracy' is a key site of struggle in contemporary South Africa.

Mosala's notion of internal ideological contestation within any and every biblical text (and not simply between biblical books) is a particularly biblical studies understanding. Nevertheless, theologians would do well to grapple with and appropriate this notion. Vellem (2020:13) cites with approval Dirkie Smit's (2008:269) argument that the notion of 'the Reformation' is a site of struggle, and he himself argues that South African 'democracy' is a site of struggle (Vellem 2020:10-13). With respect to the Bible, however, Vellem (2020:13) argues not for the recognition of the Bible as a site of struggle but for a 'decentering' of the Bible, arguing that, '[d]ecentering the Bible, Sola Scriptura, implies dislodging faith in the salvationist, authoritative paradigm of Eurocentric modernist constructs'. But even a decentred Bible remains a present Bible. What then do we do with a decentred but contextually present and still appropriated Bible?

Just how are non-persons or non-beings to engage the Bible in post-1994 South Africa? Do we take up Mosala's (1989a) summons, difficult though it is, or are there other forms of biblical engagement that are inclusive of the voiceless? 


\section{What text should we interpret and how?}

Vellem (2020:2) offers a way forward, as he reflects on the decolonial turn within democratic South Africa. Framing his reflections on biblical hermeneutics with the notion of 'decoloniality' as the questioning of 'the dominance of colonial symbols and systems of knowledge', Vellem (2020:2) goes on to problematise the Bible in this regard. He notes the debate within Black Theology about the Bible, focussing specifically on how the Bible has in more recent phases of Black Theology been 'dislodged from the center' (Vellem 2020:3). Much like Mofokeng before him, who applauded the attempts by the black youth of the 1980s 'to disavow the Christian faith and consequently be rid of the obnoxious Bible' but who recognised that the Bible would remain a resource for liberation for the foreseeable future (Mofokeng 1988:40), Vellem (2020:3) acknowledges that although the 'sources' of African Theology' are found 'everywhere' in the African landscape, the Bible remains a presence, albeit decentred. Turning to Maluleke, a regular dialogue partner in Vellem's (2020, citing Maluleke 2000:31) work, he accepts with Maluleke that:

Black theology's declaration of intent 'to use the Bible to get the land back and to get the land back without losing the Bible' is also a declaration of a most difficult enterprise. (p. 3)

The difficulty lies in the decisive question, '[w]hich biblical hermeneutics are the most appropriate and liberating for African Christians?' (Vellem 2020:3, citing Maluleke 2000:31).

With Mosala and Maluleke, Vellem (2020:3) takes as his decolonial starting point that, '[i]n the hands of the black masses, the Bible does not hold a central innocent place'. Given the Bible's complicity with colonial Christianity, not only has the Bible long 'lost its innocence as a central text for the liberation of black African masses', it has also lost its innocence as 'the Word of God' (Vellem 2020:4). African agency has taken various forms in its engagement with the Bible (Vellem 2020:2, 6-9); some have 'destroyed the Bible', whilst others 'play' with 'the Word of God' when it is preached (Vellem 2020:4, 11).

Vellem joins the trajectory within African biblical scholarship of a recognition that African Christians engage the Bible in 'play-full' or 'spirit-full' ways (Dube 1996; West 2003). Vellem (2020) invokes the Imvuselelo, a 'revival ... throng of singing, dancing and the preaching masses', where:

[T] he proclamation of the Word is celebrated with shouts of Ilzwi by the congregation that shares in the preaching, ... a 'tragicomic' celebration of the Word, democratized, dramatic and active, filled with unspeakable taints of eisegesis. (p. 11)

According to Vellem (2020:11), the Imvuselelo, notwithstanding its dimensions as a site of struggle in itself, is a significant 'zone' in which 'the non being is the interlocutor'. 'The celebration of Ilizwi' is (Vellem 2020):
[A]n expression of 'Word of God' as meaningless without ... the dialogic celebration of the participants in their suffering. Ilizwi is not an abstract and non-ideological concept of the 'Word of God' but a play, a dramatic and active bodily expression of what echoes from the zone of Non-being. (p. 11)

In this sharing of Ilizwi, no one seems to be an expert, the interpretation of the Word is shared and all members participate. The Zone of Non-being provides us with the embers of the democratization of the interpretation of the Word of God and Christian faith at least. It is visceral, it is a rupture of cognitive and cerebral approach to the politics and theological, the verbs of obedience to the trust of the marginalized. (p. 12)

Not all, however, are welcome at Imvuselelo. Imvuselelo is a site of struggle (like democracy), and requires other formations and sites in which the Bible as 'the Word of God' is destabilised and deconstructed. Imvuselelo remains what Sithembiso Zwane refers to as 'invited space' - churchcontrolled space - and even if Ilizwi processes partially reconstitute this space as 'invigorated space' which may be partially occupied by marginalised sectors, it is not yet 'invented space' - space controlled by organised formations of the marginalised (West \& Zwane forthcoming).

Whilst Ilizi processes are a good example of a James Cone-like democratised hermeneutic of reception, they do not grapple with a hermeneutic of production. Vellem seems to acknowledge as much when he cites the post-1994 prophetic writings of Allan Boesak, including specifically the plenary paper Boesak gave at the Council for World Mission's 2017 'DARE Global Forum', in Bangkok, Thailand, where Vellem himself presented a paper (Vellem 2020). In citing Boesak's (2018) now published paper, Vellem (2020:6) emphasises Boesak's hermeneutic of reception, stating that Boesak's paper 'in this gathering is but one of those excellent examples of harnessing the spontaneous knowledge of the ordinary in the interpretation of the Bible'. But Boesak's hermeneutic since 1994 has gone beyond an affirmation of a radical hermeneutic of reception. Although democratic (in Vellem's sense) reception remains foundational to Boesak's hermeneutic, Boesak has increasingly grappled with Mosala's (and my) emphasis on the necessity of an equivalent hermeneutic of production. Using language similar to Mofokeng and recognising with Vellem the embeddedness of the Bible amongst ordinary Africans, Boesak (2018) argues that:

$[P]$ recisely because the Bible remains so crucial a source of life for oppressed communities and for reflection in black liberation theology, I am not at all prepared to give up the Bible as a source of life and a powerful resource for empowerment, inspiration, and witness in that struggle against ruthless, powerful, and conscienceless forces. (p. 135)

Yet Boesak (2018) recognises that in order to continue to use the Bible prophetically he and we must work with both a hermeneutic of reception and a hermeneutic production:

My argument is four-fold: First, that the central, and most enduring, message of the Bible stands in opposition to and in rejection of both a manipulation of the message of the Bible and 
of the God of the Bible. Second, that rather than treat the Bible as a wholly compromised sacred text, irredeemably contaminated by Western imperialist readings, we should approach the Bible as sacred Scriptures appropriated by imperialist powers for the sake of domination, the subjugation of peoples, justification of the theft and exploitation of their resources, and for the purposes of ideological control.

Third, for those who hold that the central and enduring message of the Bible is liberation, freedom, justice, dignity, peace, and inclusivity, the Bible is nonetheless 'a site of struggle' (not just about the Bible but within the Bible itself) between two voices, two traditions, two understandings of specific contexts within the biblical stories, and two alternative futures for the people of God. This means that we should also add the question 'How do you read?' as critical in our approach to the Scriptures and to the readings that seek to make the Bible submissive to empire.

The fourth element of my argument builds on the distinction between 'Great tradition'-which seeks legitimacy for the dominant forces in ancient Israelite society, and exercised by the wealthy, powerful and privileged-and 'Little tradition', which calls upon the liberation energy of the exodus and confesses the God of liberation, freedom, and justice, who sides with the powerless, the wronged, the poor, the meek, and the exploited. (pp. 135-136)

This quotation reflects rather well Boesak's recognition of both biblical interpretation as a site of struggle and the Bible itself as a site of struggle. Later in this essay Boesak (2018:137-139) engages more fully with the notion of 'Bible as a site of struggle', emphasising a hermeneutic of reception, but acknowledging a place for a hermeneutic of production. He is explicit (Boesak 2018):

Reading the Bible as a history of faithful struggle against empire will include our understanding of that struggle within the texts themselves, exposing the struggle between power and powerlessness, privilege and exclusion, centering and marginalization, domination, oppression, and resistance. (p. 140)

What such a biblical hermeneutic might look like within the kind of collaborative democratic interpretive practice Vellem desires is the focus of the final section of this article. As both Vellem (2013:113) and Boesak (2015:6) acknowledge, the work of the Ujamaa Centre grapples with how to align and combine a hermeneutic of reception with a hermeneutic of production.

\section{Aligning a hermeneutic of reception and production}

The Ujamaa Centre for Community Development and Research at the University of KwaZulu-Natal in Pietermaritzburg, South Africa, has heeded Mosala's summons for more than 30 years. The sectors we interpret the Bible with, as part of locally controlled emancipatory projects (West 2016), readily identify 'glimpses of liberation and of a determinate social movement galvanised by a powerful religious ideology in the biblical text' (Mosala 1989a:40). However, because these 'glimpses' are embedded within dominant sector discourse, having been redactionally co-opted, there is the danger, as Mosala warned, of embracing the ideo-theology of the dominant as we attempt to appropriate such liberatory 'glimpses'.

Although Mosala is pessimistic about being able to recover the voices of the voiceless after successive redactions across socio-historical time and space, we should not avoid the task because it is difficult. We also should not be afraid of risking only a partial retrieval. Alongside the methods Mosala advocates to detect a voiceless presence in the redacted final form of the Bible (West 2017d), the Ujamaa Centre advocates using literary narrative methods to interpret the recovered 'text' of the voiceless. Mosala was understandably reticent about the use of literary narrative method, but only because these methods have tended to be used to read the final form of the text. But within the Ujamaa Centre we can and do use these methods to read a partially recovered text.

Furthermore, whilst Mosala is justifiably worried by interpretations that follow the ideo-theological grain of what is a co-opted text, literary narrative analysis has become more nuanced in its method since what the literary biblical scholar Denis Olson (2010:16) refers to as the 'constructive literary approaches' characteristic of the 1970s and 1980s, in which 'scholars often assumed a basic unity, structure and coherence in the text'. However, Olson (2010) continues, with the recognition of the presence of real readers and their role 'in constructing meaning from texts':

$[L]$ iterary scholars began to question the new critic's assumption about the stability of literary texts with a unified meaning. They also resisted structuralism's assumption of a set of universal binary oppositions that transcend cultural and social location. (p. 19)

Alongside this reader-centred generated recognition, textcentred approaches themselves became more focussed "in" the details of the text itself', recognising both the text's 'internal complexity' and the text's 'gaps and omissions' (Olson 2010:19). With recent developments in literary narrative analysis, the grain of the text has been destabilised from without by the reader and from within by the text's own detail and (post-structural) gaps, each of which are ideologically determined (in both senses of the English word). Such 'deconstructive literary approaches' are better equipped to do the work Mosala envisages at the textual level, and lend themselves to inclusive and collaborative work with the masses, commoners and voiceless. Using deconstructive literary narrative method, inclusive and collaborative interpretive work is able to detect more detailed 'glimpses' of the struggles that produced the text, in the text.

I will conclude this section of the article with some examples. In honouring Vuyani Vellem's relentless reminder of the centrality of class and economic analysis after 1994, as we desperately yearn for 'economic freedom in our lifetime', my examples are all from the economic domain of the Ujamaa Centre's work, what we refer to as our 'Bread Theology' 
project, with which Vuyani Vellem has been a regular collaborator (Vellem 2013).

Our preference in the Ujamaa Centre when working with the gospels is to use Mark wherever possible. Our early work using Mark's gospel was shaped by socially engaged scholarly works in which it was recognised that Mark had a particular commitment to demonstrate a Jesus who contended with dominant understandings of scripture (Mk 12:24) and dominant economic systems (see, e.g., Horsley 2001; Myers 1988; Waetjen 1989). We did extensive race and/or classoriented economic Contextual Bible Study (CBS) work on Mark 10:17-22, working with local churches to interpret this enigmatic text in apartheid South Africa, where the economic systems of racial capitalism were interrogated using Mark's version of Jesus' engagement with the (rich) man whose wealth was almost certainly obtained through systemic exploitation (Draper \& West 1989). We also worked with Mark 11:27-13:2, offering the communities we collaborated with resources for re-reading Mark's critique of the citytemple state system, centred on the Jerusalem temple (West 2011). Our CBS work on this text begins with the well-known to 'Church Theology' (Kairos 1985, 1986) section (Mk 12:4144) about the 'poor widow' who gave all she had to the Jerusalem temple treasury. Our CBS deconstructs the privatised and individualised 'faithful and sacrificial giving' theology so prevalent in South African churches by relocating this text within its literary unit (Mk 11:27-13:2) and then offering socio-historical resources to situate this text in the exploitative economic practices of the 1st-century Jerusalem temple (West 2011:435-441). The 'poor widow' is poor because she has been exploited by city-temple state economic systems.

Where we use other gospels, we are overt about how they have been redacted. Sithembiso Zwane and I have chosen to make Matthew's ideo-theological agenda apparent in Matthew's redaction of an economic parable of Jesus in Matthew 20:1-16. Our CBS is overt about Matthew's cooptation of a parable of Jesus. The parable of Jesus as he told it to the marginalised of his time, inasmuch as it can be recovered, is clearly about economic matters (Herzog 1994:79-97). Yet Matthew takes this parable and redacts it in a way that shifts its emphasis from the socio-economic domain to the ethno-religious domain (West \& Zwane 2013).

Our work deliberately, as indicated above, deconstructs 'Church Theology' interpretations of biblical texts. A further economic example is our work on the so-called 'Lord's Prayer'. Most South African Christians are familiar with this prayer, but almost every version recited in church or at home or at Imvuselelo is a 'Church Theology' version. We choose Matthew's version of this prayer (Mt 6:9-13) because Matthew's source is probably closest to the prayer Jesus taught the marginalised sectors of his time. The focus of the prayer is clearly actual 'bread' and actual 'debt'. Again, by attempting to reconstruct the actual prayer Jesus taught from Matthew's redaction, we recover a remarkably radical economic manifesto which we offer to local communities through CBS (West 2017c).
We work with the Old Testament in similar ways, drawing on the work of the two comrades, Itumeleng Mosala and Gunther Wittenberg, who have indelibly shaped the biblical approach of the Ujamaa Centre. We heed Mosala's caution about the ideo-theological agenda of any text's final form and we recognise with Wittenberg (2007) the presence of 'resistance theology' voices that have been redacted but which can be recovered.

The story of Joseph (Gn 37-50) is a well-known story within African Christianity, usually interpreted in 'Church Theology' ways. Yet in the midst of the story are two fragments of text, which are clearly about economic contestation (Gn 41:47-49 and Gn 47:13-25). In the first fragment, Joseph 'gathers/collects' the surplus from people during the years of plenty and stores it in the city-temple state-controlled cities. In the second fragment, Joseph sells what he has taken back to the people, through a carefully narrated set of exploitative practices until the people are enslaved (Ramantswana 2016:194, 2017:81). These two fragments are the remnants of economic contestation in ancient Israel. In our CBS work on this story we offer both socio-historical and literary-narrative forms of engagement with this text. This economic narrative has almost disappeared, it is almost an 'absence' (Mosala 1989a:188), but an absence whose voice can still be heard through CBS (West 2018a).

My final example is work in progress on the economic narrative within the story of the division between the northern and southern kingdoms of ancient Israel. The story about the division between 'Israel' in the north and 'Judah' in the south has been through a number of redactions. The final redaction we have in the final form of our Bibles frames the division as the result of religious and sexual immorality (1 Ki 11:1-13). However, given the version of the story we have in the Septuagint (3 Reigns 12:1-18), it is clear that at some socio-historical moment the division was framed as a result of contestation between two kings, Rehoboam in the south and Jeroboam in the north (1 Ki 11:38-12:3). The economic narrative, however, is evident within the canonical version of 1 Kings 12:1-18, but has to be recovered by ignoring the wider redactional framing and the redactional additions in verses $2-3 a, 15 b$ and 17 . What remains is a narrative in which the people confront the new king, Rehoboam, demanding systemic economic change (West 2018b). The story, once recovered, lends itself to the literary narrative analysis. Given the post-1994 South African context of the economic exploitation of the state, what is particularly interesting is that it is the elite youth as beneficiaries of the city-temple state economic system implemented by Solomon who insist that Rehoboam not only retain but also expand Solomon's economy of extraction.

As discussed above, CBS embraces both Mosala's hermeneutic of production and Vellem's democratic hermeneutic of reception. We work with biblical texts that have been sociohistorically recovered from redactional co-optation, and we 
then offer these texts of kin voiceless sectors in the ancient world to contemporary organised sectors of the voiceless, using both literary narrative and socio-historical analyses.

\section{Conclusion}

The fact the Bible is a site of struggle - inherently, intrinsically and indelibly - is not in doubt within contemporary South African Black Theology. The questions that confront post-1994 Black Theology are about who its interlocutors should be. Vuyani Vellem's answer, aligning him with Black Theology's trajectory since its inception, is that Black Theology's interlocutor after 1994 should remain the contemporary voiceless. In this article, I have argued that Vellem's question about interlocution poses another related question, namely, 'what biblical text should be interpreted?' Drawing on Mosala's 1980s work, I make it clear that this does not mean picking and choosing what text suits the Black Theology project; it means interrogating each and every biblical text for its ideo-theological agenda. If we are to take the claim that the Bible is a site of struggle seriously, then we must recognise that every canonical biblical text is ideo-theologically comprised or co-opted. If this is the case, then we must forge ways of interpreting that are both democratic, as Vellem insists, and, as is the Ujamaa Centre's praxis, attentive to a hermeneutics of production within ancient sites of struggle.

\section{Acknowledgements Competing interests}

The author declares that he has no personal or financial relationships that may have inappropriately influenced him in writing this research article.

\section{Author's contributions}

G.O.W. is the sole author of this research article.

\section{Ethical considerations}

This article followed all ethical standards for research without direct contact with human or animal subjects.

\section{Funding information}

This research received no specific grant from any funding agency in the public, commercial or not-for-profit sectors.

\section{Data availability statement}

Data sharing is not applicable to this article as no new data were created or analysed in this study.

\section{Disclaimer}

The views and opinions expressed in this article are those of the author and do not necessarily reflect the official policy or position of any affiliated agency of the author.

\section{References}

Boesak, A.A., 2015, Kairos, crisis, and global apartheid: The challenge to prophetic resistance, Palgrave Macmillan, New York, NY.

Boesak, A.A., 2018, 'Babblers to the rabble, prophets to the powerful: Mission in the context of empire', in J. Havea (ed.), Religion and power, pp. 133-148, Lexington Books, Lanham, MD.

Cone, J.H., 1975, God of the oppressed, Seabury Press, New York, NY.

Cone, J.H., 1979, 'A black American perspective on the future of African theology', in K. Appiah-Kubi \& S. Torres (eds.), Pan-African conference of Third World theologians, December 17-23, 1977, Accra, Ghana, pp. 176-186, Orbis Books, Maryknoll, New York, NY.

Draper, J.A. \& West, G.O., 1989, 'Anglicans and scripture in South Africa', in F. England \& T.J.M. Paterson (eds.), Bounty in bondage: The Anglican Church in Southern Africa: Essays in honour of Edward King, Dean of Cape Town, pp. 30-52, Ravan, Africa: Essays

Dube, M.W., 1996, 'Readings of Semoya: Batswana women's interpretations of Matt. 15:21-28', Semeia 73, 111-129.

Frostin, P., 1988, Liberation theology in Tanzania and South Africa: A First World interpretation, Lund University Press, Lund.

Gutiérrez, G., 1978, 'Two theological perspectives: Liberation theology and progressivist theology', in S. Torres \& V. Fabella (eds.), The emergent gospel: Theology from the underside of history, pp. 227-255, Orbis, Maryknoll, New York, NY.

Herzog, W.R., 1994, Parables as subversive speech: Jesus as pedagogue of the oppressed, Westminister, Louisville, KY.

Horsley, R.A., 2001, Hearing the whole story: The politics of plot in Mark's gospel, Westminster John Knox, Louisville, KY.

Kairos, 1985, Challenge to the Church: The Kairos document: A theological comment on the political crisis in South Africa, The Kairos theologians, Braamfontein.

Kairos, 1986, The Kairos document: Challenge to the church: A theological comment on the political crisis in South Africa, rev. 2nd edn., Skotaville, Braamfontein.

Maluleke, T.S., 1996, 'Do I, with my excellent PhD, still need affirmative action? The contribution of Black theology to the debate', Missionalia 24(3), 303-321.

Maluleke, T.S., 2000, 'The rediscovery of the agency of Africans: An emerging paradigm of post-cold war and post-apartheid black and African theology', Journal of Theology for Southern Africa 108, 19-37.

Mofokeng, T., 1988, 'Black Christians, the Bible and liberation', Journal of Black Theology 2(1), 34-42.

Mosala, I.J., 1986, 'The use of the Bible in Black theology', in I.J. Mosala \& B. Tlhagale (eds.), The unquestionable right to be free: Essays in black theology, pp. 175-199, Skotaville, Johannesburg.

Mosala, I.J., 1989a, Biblical hermeneutics and black theology in South Africa, Eerdmans, Grand Rapids, MI.

Mosala, I.J., 1989b, 'Prospects for the future and building of alliances', in S.S. Maimel \& D.N. Hopkins (eds.), We are one voice: Black theology in the USA and South Africa, pp. 139-148, Skotaville Publishers, Johannesburg.

Mosala, IJ., 1996, 'Race, class, and gender as hermeneutical factors in the African independent churches' appropriation of the Bible', Semeia 73, 43-57.

Myers, C., 1988, Binding the strong man: A political reading of Mark's story of Jesus, Orbis Books, Maryknoll, New York, NY.

Olson, D.T., 2010, 'Literary and rhetorical criticism', in T.B. Dozeman (ed.), Methods for Exodus, pp. 13-54, Cambridge University Press, Cambridge.

Ramantswana, H., 2016, 'Decolonising biblical hermeneutics in the (South) African context', Acta Theologica 36(suppl 24), 178-203.

Ramantswana, H., 2017, 'Decolonial reflection on the landlessness of the Levites' Journal of Theology for Southern Africa 158, 72-91.

Smit, D.J., 2008, 'What does it mean to live in South Africa and to be reformed?', Reformed World 58(4), 263-283.

Vellem, V.S., 2012, 'Interlocution and Black theology of liberation in the 21st century: A reflection', Studia Historiae Ecclesiasticae 38(1), 345-360.

Vellem, V.S., 2013, 'A critical black analysis of the church's role in the post-apartheid struggle for socio-economic justice', Studia Historiae Ecclesiasticae 39(2), $113-130$.

Vellem, V.S., 2014, 'The task of urban black public theology', HTS Theological Studies 70(3), Art. \#2728, 6 pages. https://doi.org/10.4102/hts.v70i3.2728

Vellem, V.S., 2020, 'Hermeneutical embers from the "zone of non-being"', in J. Havea (ed.), Mission and context, n.p., Lexington Books, Lanham, MD.

Waetjen, H.C., 1989, A reordering of power: A socio-political reading of Mark's gospel, Fortress, Minneapolis, MN.

West, G.O., 2003, 'From the Bible as bola to biblical interpretation as marabi: Tlhaping transactions with the Bible', in J.A. Draper (ed.), Orality, literacy, and colonialism in Southern Africa, pp. 41-55, Society of Biblical Literature, Cluster Publications, Atlanta, GA.

West, G.O., 2011, 'Do two walk together? Walking with the other through contextual Bible study', Anglican Theological Review 93(3), 431-449.

West, G.O., 2013, 'Liberation hermeneutics', in S.L. McKenzie (ed.), The Oxford Encyclopedia of biblical interpretation, pp. 507-515, Oxford University Press, Oxford. 
West, G.O., 2015, 'Africa's liberation theologies: An historical-hermeneutical analysis', in S.D. Brunn (ed.), The changing world religion map: Sacred places, identities, in S.D. Brunn (ed.), The changing world religion map: Sacres
pratics, pp. 1971-1985, Springer, Dordrecht.

West, G.O., 2016, 'Recovering the biblical story of Tamar: Training for transformation, doing development', in R. Odén (ed.), For better, for worse: The role of religion in development cooperation, pp. 135-147, Swedish Mission Council, Halmstad.

West, G.O., 2017a, 'African liberation theology', in D.T. Ngong (ed.), A new history of African Christian thought: From Cape to Cairo, pp. 122-135, Routledge, New York, NY.

West, G.O., 2017b, 'The co-optation of the Bible by "Church theology" in postliberation South Africa: Returning to the Bible as a "site of struggle",', Journal of Theology for Southern Africa 156, 185-198.

West, G.O., 2017c, 'The Lord's prayer as economic renewal', in A. Burkhardt \& S. Sinn (eds.), Global perspectives on the reformation: Interactions between theology, politics and economics, pp. 85-94, Evangelische Verlagsanstalt, Leipzig.

West, G.O., 2017d, 'Redaction criticism as a resource for the Bible as "a site of struggle"', Old Testament Essays 30(2), 525-545. https://doi.org/10.17159/2312 3621/2017/v30n2a19

West, G.O., 2018a, 'Facilitating interpretive resilience: The Joseph story (Genesis 37-50) as a site of struggle', Acta Theologica 26, 17-37. https://doi.org/10.18820/ 23099089/actat.Sup26.1
West, G.O., 2018b, 'Unmasking state theology', in S. Heinrichs (ed.), Unsettling the word: Biblical experiments in decolonization, pp. 82-86, Mennonite Church, Word:

West, G.O., 2019a, 'Scripture as a site of struggle: Literary and socio-historical resources for prophetic theology in post-colonial, post-apartheid (neo-colonial?) South Africa', in J. Havea (ed.), Scripture and resistance, pp. 149-163, Lexington, New York, NY.

West, G.O., 2019b, 'The Bible and/as the lynching tree: A South African tribute to James H. Cone', Missionalia 46(2), 236-254. https://doi.org/10.7832/46-2-312

West, G.O., 2020, 'Serving the sighs of the working class in South Africa with Marxist analysis of the Bible as a site of struggle', Rethinking Marxism 32(1), 41-65. https://doi.org/10.1080/08935696.2019.1694287

West, G.O. \& Zwane, S., 2013, “"Why are you sitting there?" Reading Matthew 20:1-16 in the context of casual workers in Pietermaritzburg, South Africa', in N.D. Wilkinson \& J. Grimshaw (eds.), Matthew: texts@contexts, pp.175-188, Fortress Press, Minneapolis, MN.

West, G.O. \& Zwane, S., [forthcoming], 'Re-reading 1 Kings 21:1-16 between community-based activism and university-based pedagogy', Journal for Interdisciplinary Biblical Studies.

Wittenberg, G.H., 2007, Resistance theology in the Old Testament: Collected essays, Cluster Publications, Pietermaritzburg. 